\title{
Effect of Early Treatment of Hypertension in Acute Cerebral Hemorrhage: New Evidences
}

\author{
Akut Serebral Kanamada Hipertansiyonun Erken Tedavisi: \\ Yeni Kanitlar
}

Acute hypertensive response is common in patients with intracerebral hemorrhage and it is believed to increase mortality by causing hematoma enlargement. In order to prove this hypothesis, the "Intensive Blood Pressure Reduction in Acute Cerebral Hemorrhage Trial-2 (INTERACT-2)" was performed (data from this study was published in the $3^{\text {rd }}$ issue of Turkish Journal of Neurology in 2013). Interestingly, this study demonstrated that intensive antihypertensive treatment applied within 6 hours after the start of acute cerebral hemorrhage symptoms did not change rates of death or severe disability; however, disability scores were lower and quality of life was better in patients who took intensive antihypertensive treatment (1).

In the more recent "Antihypertensive Treatment of Acute Cerebral Hemorrhage-2 (ATACH-2)" study, intensive antihypertensive treatment was initiated within the first 4.5 hours and applied for 24 hours (2). Patients with at least one systolic blood pressure (BP) value equal to or above $180 \mathrm{mmHg}$ were randomized into 2 groups. One of the groups took the standard treatment (BP target 140-179 $\mathrm{mmHg}$ ) and the other group took intensive treatment (BP target 110-139 $\mathrm{mmHg}$ ). Before randomization, decreasing systolic BP below $140 \mathrm{mmHg}$ was allowed but patients whose BP decreased below $140 \mathrm{mmHg}$ were excluded from the study. The initial and $24^{\text {th }}$ hour computed tomography scans were obtained to compare hematoma sizes, and clinical evaluations were performed via telephone calls after 1 month and in clinical examinations at the $3^{\text {rd }}$ month. The neurologic status of the patients was evaluated using the modified Rankin scale, European Quality of Life Survey (EQLS) questionnaire (5 dimensions), and neurologic examination.

This study included 1000 patients over 4 years and no difference was found between these 2 groups according to death or disability, hematoma enlargement, neurologic deterioration within 24 hours, severe treatment related adverse effects within the first 72 hours, any adverse effect within the first 3 months, or any of the parameters of the EQLS questionnaire parameters (2).

In conclusion, according to the results of this study, decreasing systolic BP to $110-139 \mathrm{mmHg}$ did not yield additional clinical benefit compared with decreasing BP below 140-179 mmHg. However, the results of ATACH-2 should not be generalized to patients with large intracerebral hematomas whose intracranial pressure is increased and perfusion is disturbed; a possible benefit from early and intense antihypertensive treatment should be kept in mind in these patients.

When comparing results of ATACH-2 with INTERACT-2, which demonstrated that early and intensive treatment may be helpful, it should be noted that there were differences such as earlier treatment time, much lower rates of primary treatment failure, systolic BP equal to or above $180 \mathrm{mmHg}$ in all patients, and lower BP in the intensive treatment group in ATACH-2.

\section{References}

1. Anderson CS, Heeley E, Huang Y, Wang J, Stapf C, Delcourt C, Lindley R, Robinson T, Lavados P, Neal B, Hata J, Arima H, Parsons M, Li Y, Wang J, Heritier S, Li Q, Woodward M, Simes RJ, Davis SM, Chalmers J; INTERACT-2 Investigators. Rapid blood-pressure lowering in patients with acute intracerebral hemorrhage. N Engl J Med 2013;368:2355-2365.

2. Qureshi AI, Palesch YY, Barsan WG, Hanley DF, Hsu CY, Martin RL, Moy CS, Silbergleit R, Steiner T, Suarez JI, Toyoda K, Wang Y, Yamamoto H, Yoon BW; ATACH-2 Trial Investigators and the Neurological Emergency Treatment Trials Network. Intensive blood-pressure lowering in patients with acute cerebral hemorrhage. N Engl J Med 2016;375:1033-1043.


Phone: +902124142000 E-mail: drtuncaygun@gmail.com

Received/Geliş Tarihi: 21.08.2016 Accepted/Kabul Tarihi: 21.08.2016

${ }^{\circ}$ Copyright 2016 by Turkish Neurological Society

Turkish Journal of Neurology published by Galenos Yayınevi. 